\title{
The Value of the Stability of the Law: A Perspective on the Role of the Emperor in Political Crises
}

\author{
Francesco Bono
}

\section{$1 \quad$ Emperors and Usurpers in Conflict in Late Antiquity}

The great Church father Augustine, speaking from the pulpit of the Tricilarum Basilica around 413, offered a comment on the Apostle Paul's passage Non regnet peccatum in vestro mortali corpore. ${ }^{1}$ The bishop of Hippo urged the people not to be overcome by the lust of the flesh, describing this situation as a civil war of the fifth century. ${ }^{2}$ Christians faced the conflict between flesh and spirit just as citizens of the empire faced the choice between a usurper, or tyrannus, ${ }^{3}$ and an emperor:

Languor iste tyrannus est. Si vis te tyranni esse victorem, Christum invoca imperatorem.

This disease is like a tyrant. If you want to defeat this tyrant, you shall invoke Christ the real emperor.

Augustine's speech, in its imagery, had a direct connection with the daily life of Christian believers. The bishop's audience had experienced such a clash between a usurper and the emperor; ${ }^{4}$ for in that very same year, Heraclanius, comes Africae, had been declared hostis publicus. ${ }^{5}$

1 Rom. 6.12: For this reason do no let sin be ruling in your body, which is under the rule of death.

2 Aug., Serm. 30.41; on this text: S. Poque, Le langage symbolique dans la prédication d'Augustin d'Hippone. Images héroiques I (Paris 1984), 34-35; 57-6o.

3 On the meaning of tyrannus: T.D. Barnes, 'Oppressor, persecutor, usurper: the meaning of tyrannus in the fourth century', in G. Bonamente and M. Meyer (eds.), Historiae Augustae colloquium Barcinonense (Bari 1996), 55-65; V. Neri, 'L'usurpatore come tiranno nel lessico politico della Tarda Antichità, in F. Paschoud and J. Szidat (eds.), Usurpationen in der Spätantike. Akten des Kolloquiums Staatsstreich und Staatlichkeit 6.-10. März 1996 Solothurn/Bern (Stuttgart 1997), 71-87.

4 In Aug. Serm. Denis 16.1, a sermon preached in Basilica Novarum, Augustine may have referred again to Heraclianus: Inimicus est? Homo est. Hostis est? Homo est (Is he a personal enemy? He is a man still. Is he a public enemy? He is a man still). See, S. Lancel, Saint Augustine (Paris 1999), 268.

5 CTh. 9.40.21.

(C) KONINKLIJKE BRILL NV, LEIDEN, 2019 | DOI:10.1163/9789004400474_005Francesco Bono - 9789004400474 
Usurpation was very frequent in the Late Empire, as depicted by the historical sources. Beside the list of triginta tyranni in the Historia Augusta, ${ }^{6}$ Orosius mentions a catalogus tyrannorum in his Historiae adversus paganos when describing the usurpers Constans, Maximus, and Jovinus in the year $409 .{ }^{7}$ Furthermore, in Polemius Silvius' annotated Julian calendar in honor of Eucherius (Bishop of Lyon) of December 448, we find a copy of an enumeratio principum cum tyrannis, a list of Roman emperors and usurpers from Julius Caesar to Theodosius II and Valentinian III. ${ }^{8}$

Usurpation in Late Antiquity took diverse forms, ranging from emperors being declared enemies of the state to rebellious generals. Nonetheless, usurpation constituted a political problem, not only a military one, because the claimant wanted to be recognized as a legitimate ruler ${ }^{9}$ and acted as such. ${ }^{10}$ The opposition between an emperor and his rival for the title of Augustus had been a political matter since its genesis. Once such usurpers were suppressed, the legitimate emperors continued a propaganda war against their defeated opponents. ${ }^{11}$ Late imperial coinage celebrated the successes over the usurpers through depictions of the goddess Victoria promoting the triumph of the emperor. ${ }^{12}$ Monuments were another medium of representation for a

6 Hist. Aug., Trig. tyr.

7 Oros., Hist. 7.42; G. Gaggero, 'Le usurpazioni africane del IV-V secolo d.C. nella testimonianza degli scrittori cristiani', L'Africa romana 10 (1993), 1111-1127.

8 Th. Mommsen, Chronica minora, I [MGH AA XIII] (Berolini 1898), 518-551, esp. 520-523. On this text, R.W. Burgess, 'Principes cum tyrannis. Two studies on the Kaisergeschichte and its tradition', The Classical Quarterly 43 (1993), 491-50o.

9 Modern scholarship connects the phenomenon of usurpation with the absence of an institutionalized process governing the transfer of power at the head of the empire; see: F. Amarelli, Trasmissione, rifiuto, usurpazione. Vicende del potere degli imperatori (Naples 1998); E. Flaig, 'Für eine Konseptionalisierung der Usurpation in Spätrömischen Reich', in Paschoud and Szidat 1997 op. cit. (n. 3), 15-34; J. Szidat, Usurpator tantinominis. Kaiser und Usurpator in der Spätantike (337-476 n. Chr.) (Stuttgart 2010). Still relevant is the formulation already found in Bartolo da Sassoferrato's Tractatus de tyranno: ex predictis constat quod tyrannus civitatis est qui in civitate non iure principatur (D. Quaglioni, Politica e diritto nel Trecento italiano. Il De tyranni di Bartolo di Sassoferrato (1314-1357) (Florence 1983), 184); and very perspicuous, even in its brevity, is the definition given by John Locke (Two treatises of government (London 169o), 420): "usurpation is the exercise of power which another hath a right to".

10 S. Benoist, 'Usurper la pourpre ou la difficile vie des ces "autres" principes', in S. Benoist and C. Hoët (eds.), La vie des autres. Histoire, prosopographie, biographie dans l'Empire romain, (Villeneuve d'Ascq 2013), 37-61.

11 The scholarly debate on the concept of propaganda in Roman history is carefully explained by: A. Maranesi, Vincere la memoria, costruire il potere. Costantino, i retori, la lode dell'autorità e l'autorità della lode (Sesto San Giovanni 2016), 19-26. 
legitimate ruler. The Senate built an arch at the foot of the Palatine to commemorate Constantine's victory against Maxentius at the Milvian Bridge, ${ }^{13}$ Theodosius I decided to erect an obelisk on the central spina of the hippodrome at Constantinople in order to celebrate his victory against the usurper Magnus Maximus. ${ }^{14}$ Finally, public ceremonies indicated the return of peace after the usurper's defeat. ${ }^{15}$ A triumph of Honorius in Rome in 416, for instance, symbolically ended the political crises caused by attempted usurpations in Gaul.

In view of these various "imperial" manifestations, sharing an intent to reaffirm the emperor's legitimacy, a question arises: what did the law say? The war of a legitimate emperor against a usurper continued on an administrative and legal level. A usurper used the same legal forms as a legitimate ruler, ${ }^{16}$ because he usurparet imperium. ${ }^{17}$ For example, Eugenius ${ }^{18}$ appointed consuls and sent his officials to Africa, and he provided grain supplies as well. ${ }^{19}$ Usurpers typically also enacted a number of statutes and/or grants of beneficia and privilegia. $^{20}$

Consequently, usurpation created a fracture in the legal order because emperors, after defeating their rivals, removed the effects that the usurpations had produced. The condemnation of a usurpation to oblivion was carried out with legal instruments. For the period that runs from Constantine to Theodosius II, imperial constitutions are the most vital witnesses of the actions taken by the emperors. On the one side, in public law, emperors professed to be restoring the status quo ante; in particular, they tended to order that enactments

of the Roman West. c. 383-c. 408', in G. Greatrex and H. Elton (eds.), Shifting Genres in Late Antiquity (Farnham 2015), 157-171.

13 A. Bravi, 'Larco di Costantino. Un monumento dell'arte romana di rappresentanza', Costantino I. Enciclopedia costantiniana (Rome 2013), 599-613.

14 CIL 3.737. The inscription, on the base of the monument, displays the palm of victory for extinctis tyrannis. See, B. Kiilerich, The Obelisk Base in Constantinople. Court Art and Imperial Ideology (Rome 1993).

15 J. Wienand, 'O tandem felix civili, Roma, victoria! Civil-war triumphs from Honorius to Constantine and back', in J. Wienand (ed.), Contested Monarchy. Integrating the Roman Empire in the Fourth Century AD (Oxford 2015) 169-197.

16 Benoist 2013, op. cit. (n. 10), 37-61.

17 Paneg. Lat. 7.16.1.

18 H. Leppin, Teodosio il Grande (Naples 2003), 247-255.

19 R. Delmaire, 'Les usurpateurs du Bas-Empire et le recrutement des foncionnaires (Essai de réflexion sur les assises du pouvoir et leurs limites)', in Paschoud and Szidat 1997 op. cit. (n. 3), 111-126.

20 The concession of fundi perpetui iuris is recorded for the usurper Maximus by: CTh. 15.14.10. 
issued under the usurper should be nullified (rescissio actorum). ${ }^{21}$ On the other side, they tended to confirm all private legal acts which had been enacted during the time of "tyranny", because the danger of collapse in social and economic relationships had to be avoided.

Even if different points of view emerge from public and from private law, imperial statutes show a consistent image of what constituted a legitimate ruler. As words of the emperor himself, constitutions are part of the ideological system centred on the figure of the emperor and made up of many different elements, for example rhetorical texts as Panegyrics or images on coins. All these objects and texts played a role in the representation and promotion of imperial power to the population of the Roman empire. By examining several constitutions from the Theodosian Code, ${ }^{22}$ I argue in this paper that the imperial statutes promote the emperor who has vanquished a usurper as the person who re-established order and protected the stability of the law. ${ }^{23}$

\section{Annulling a Usurper's Legislation: Between Commands and Political Communication}

Removal of a rival generally forced emperors and their administration to review the enactments that the usurper had issued. The question is not simple, as in some cases a usurper may have exercised power for a long period and over an extensive area.

Constantine, to use an important example, had to solve such a situation after defeating Licinius, who had been Augustus for more that fifteen years. Constantine branded him a tyrannus - a term which defines a political enemy but also a usurper-in order to recast his own conquest of the East as a restoration of

21 G. Sautel, 'Usurpations du pouvoir impérial dans le monde romain e rescissio actorum', in Studi in onore di Pietro de Francisci III (Milan 1956), 463-491.

22 On the code's title De infirmandis his, quae sub tyrannis aut barbaris gesta sunt: A. Lovato, 'Osservazioni minime sulla composizione del titolo De infirmandis his, quae sub tyrannis aut barbaris gesta sunt del Teodosiano (15.14)', Atti dell'Accademia Romanistica Constantiniana 20 (2014), 345-355; Id., 'Les actes juridiques privés, entre légitimité et usurpation', in J.J. Aubert and P. Blanchard (eds.), Droit, religion et société dans le Code Théodosien (Geneva 2009), 401-408; M.V. Escribano, 'La ilegitimidad politica en los textos historiograficos y juridicos tardios (Historia Augusta, Orosius, Codex Theodosianus)', Revue internationale des droits de l'antiquité 44 (1997), 85-120; J.J. Aubert, 'La validité des actes des déchus (Codex Theodosianus XV 14)', The Journal of Juristic Papyrology 24 (2016), 581-595.

23 See also the contribution by Daalder in this volume on the role of imperial enactments and legal decisions as part of the ideological construct of the 'good' emperor. 
liberty and the rule of law. Constantine addressed an epistula to the praetorian prefect Constantius, ordering that all inhabitants should obey only his constitutions and the vetus ius because the constitutions and the leges of Licinius ${ }^{24}$ had been declared void, probably by an edictum previously issued:

Imp. Constantinus a. ad Constantium praefectum praetorio. Remotis Licini tyranni constitutionibus et legibus omnes sciant veteris iuris et statutorum nostrorum observari debere sanctionem. Proposita XVII kal. iun. Crispo III et Constantino III caess. conss. ${ }^{25}$

Emperor Constantine Augustus to Constantius, Praetorian Prefect. All men shall know that the constitutions and laws of the tyrant Licinius are abolished and that the sanctions of ancient law and of Our statutes must be observed. Posted on the seventeenth day before the kalends of June in the year of the third consulship of Crispus and Constantine CaesarsMay (December) 16, $324^{26}$

The words used in the constitution are extremely clear. They communicate the point of view of the winner, who wants to show strength and authority. The existing body of law from then on included ancient law followed by the enactments of Constantine, while the constitutions of the usurper completely lost their power. ${ }^{27}$ The vacuum that was potentially created by the deletion of Licinius' laws was filled by the constitutions of Constantine, who connected his own legislation to the ancient law (ius vetus), thus creating a continuation of the legal order. The constitution, however, was less effective in practice, since the historical record has preserved many traces of Licinius the legislator. ${ }^{28}$ Moreover, coeval Christian sources confirm that Constantine abrogated

24 S. Corcoran, 'Hidden from history: the legislation of Licinius', in J. Harries and I. Wood (eds.), The Theodosian Code. Studies in the Imperial Law of Late Antiquity (London 1993), 97-119.

25 CTh. 15.14.1.

26 C. Pharr (ed.), The Theodosian Code and Novels and the Sirmondian Constitutions (Princeton 1952), 437. On the correction of the date (from May to December), see, O. Seeck, Regesten der Kaiser und Papste fur die Jahre 311 bis $476 \mathrm{n}$. Chr. Vorarbeit zu einer Prosopographie der christlichen Kaiserzeit (Stuttgart 1919), 174; Corcoran 1993 op. cit. (n. 24), 99.

27 In another constitution, concerning private contracts, Constantine restated his decision to cancel all the legislation of the usurper Licinius: CTh. 15.14.2 Tyranni et iudicum eius gestis infirmatis. See, Corcoran 1993, op. cit. (n. 24); J.N. Dillon, The Justice of Constantine. Law, Communication, and Control (Ann Arbor 2012), 95-96.

28 Corcoran 1993 op. cit. (n. 24), 105-119. 
only the enactments against the church. ${ }^{29}$ The proclaimed complete annulment of Licinius' legislation seems rather part of the political message of the Constantinian regime, ${ }^{30}$ absorbed in manipulating the past and celebrating a new vision of government.

The link between the emperor and ancient law (vetus ius), stressed in CTh. 15.14.1, was already expressed in an earlier constitution that Constantine issued in an analogous situation in 313, namely the overthrow of Maxentius. The arrival of Constantine in Rome was followed by a widespread promotion of his person, which had to counteract the city's preference for his rival. Constantine characterized his opponent as a tyrant, providing, at the same time, a revealing self-portrait in the role of liberator urbis. ${ }^{31}$ In this context of vilifying Maxentius, Constantine dealt with his enactments:

Idem a. Antiocho praefecto vigilum. Quae tyrannus contra ius rescripsit non valere praecipimus, legitimis eius rescriptis minime impugnandis. Dat. viII id. iul. Romae Constantino a. viI et Constantio caes. conss. ${ }^{32}$

The same Augustus to Antiochus, Prefect of the City Guard. We direct that if the tyrant issued any rescripts contrary to law, they shall have no validity, but his lawful rescripts shall not be impugned. Given on the eighth day before the ides of July at Rome in the year of the seventh consulship of Constantine Augustus and the consulship of Constantius Caesar.-July 8, 326; January 6 , $313 \cdot 33$

In CTh. 15.14.1, Constantine referred to the "tyrant" Licinius's enactments, leges and constitutiones. In the statute about Maxentius, the same oblivion was imposed on the imperial rescripts, i.e. the answers to petitions, that the usurper had pronounced "against the law" (contra ius). ${ }^{34}$

29 Soz., $H E$ 1.8; Eus., De vita Constantini 43.

30 The communicative schemes used by Constantine are analysed by: Dillon 2012, op. cit (n. 27); A. Maranesi, 'Demersa quondam tyrannidis impiae malis: reconsidering the political storytelling in the early Constantinian age', Koinonia 41 (2017), 211-228.

31 E. Marlowe, 'Liberator urbis suae. Constantine and the ghost of Maxentius', in B.C. Ewald and C.F. Noreña (eds.), The Emperor and Rome. Space, Representation, and Ritual (Cambridge 2010), 199-210.

CTh. 15.14.3; The subscriptio of the constitution is emended by: Seeck 1919 op. cit. (n. 26), 16 o.

33 Pharr 1952 op. cit. (n. 26), 437.

34 The same principle of law is affirmed by Constans in CTh. 15.14.5. The legislation on rescripta contra ius is analysed by: P. Voci, 'Note sull'efficacia delle costituzioni imperiali. 
However, the acts of Maxentius were not abolished in their entirety, for Constantine ordered that the lawful rescripts were not to be challenged. It is important to focus on this decision, because the lawful rescripts received their validity not only because they complied with the ius vetus, but also because Constantine forbade opposition against them. The constitution thus points to an implied evaluation of what valid law is. Even if the usurper as illegitimate legislator has no competence to make law, and his acts must therefore be abolished, some of his rescripts may be granted existence because the legitimate emperor gives them a new life in the world of the law. The criterion that allows these rescripts to retain their validity is their adherence to the ius vetus. In other words, the non-existence of the usurper's acts can be overcome by the connection between the ius vetus and the legitimate emperor; the former exists independently, the latter is the guarantor of the body of law in its entirety.

The sources show that the discourse linking the emperor and the ius found expression in various ways, even though in terms of semantics and ideology the range was quite narrow. The virtue of justice in the legitimate ruler is more intensely denoted as opposed to the iniquity of the usurper. For instance, in October 388 , Theodosius I condemned every law and verdict that Magnus Maximus $^{35}$ had conceived during his usurpation: ${ }^{36}$

[Impp. Valentinianus et Theodosius et Arcadius] aaa. Trifolio praefecto praetorio. Omne iudicium, quod vafra mente conceptum iniuriam, non iura reddendo Maximus infandissimus tyrannorum credidit promulgandum, damnabimus. Nullus igitur sibi lege eius, nullus iudicio blandiatur. Dat. vi Id. Octob. Mediolano Theodosio a. II et Cynegio conss. ${ }^{37}$

Emperors Valentinian, Theodosius, and Arcadius Augustuses to Trifolius, Praetorian Prefect. We condemn every decision which Maximus, the most nefarious of tyrants, conceived in his crafty mind and supposed that he

I. Dal principato alla fine del IV secolo', in P. Voci, Studi di diritto romano, II (Padova 1985), 307-309; Id., 'Note sull'efficacia delle costituzioni imperiali. II. Il v secolo', in Voci 1985 op. cit., $365-366$.

35 H.R. Baldus, 'Theodosius der Grosse und die Revolte des Magnus Maximus. Das Zeugnis der Münzen', Chiron 14 (1984), 175-192.

36 T. Honoré, Law in the Crisis of Empire. 379-455AD. The Theodosian Dynasty and its Quaestors (New York 1998), 59 n. 6 remarks that, although Maximus laws were nullified, the consulship of Evodius, praetorian praefect under Maximus, is acknowledged in: CTh. 8.5.48; CTh. 3.4.1; CTh. 2.33.2; CTh. 12.6.21. 
should promulgate, thus rendering injustice instead of justice. Therefore, no man shall boast about any law or decision of the tyrant. Given on the sixth day before the ides of October at Milan in the year of the second consulship of Theodosius Augustus and the consulship of Cynegius.October 10, $388 .{ }^{38}$

Maximus was described as the most nefarious and the most monstrous of the usurpers. ${ }^{39} \mathrm{He}$ devised laws and judgments with a wily mind, and he supposed that he should promulgate them. In reality, according to Theodosius, he was not a legitimate lawgiver, he was a source of injustice: he did wrong, rather than making law (non iura reddendo). The strong language of the constitution made the abstract idea of justice appear in the figure of Theodosius. The emperor was the personification of this principle, and his authority took away all the effects of the usurper's legal actions, in order that no-one could take advantage of any law or decision of Maximus.

We can thus say that the usurper is the living sign of iniuria, i.e. the absence of the law, while the emperor is the source of the justice. The same characterization is adopted by the rhetor Pacatus. His panegyric dedicated to Theodosius has the usurper's suppression as its major theme and shows a shared background with the text of the constitution. While the usurper Magnus Maximus carries with him perfidia, nefas, and iniuria, the legitimate emperor is the one who gives fides, fas and ius:

Tecum fidem, secum perfidiam; tecum fas, secum nefas; tecum ius, secum iniuriam; tecum clementiam pudicitiam religionem, secum impietatem libidinem crudelitatem et omnium scelerum potremorumque vitiorum.

On your side there was loyalty, on his, treachery; you had right on your side; he, wrong; you had justice, he injustice; you had clemency, modesty, religious scruple, he impiety, lust, cruelty and a whole company of the worst crimes and vices. ${ }^{40}$

$38 \quad$ Pharr 1952 op. cit. (n. 26), 437.

39 The constitutions of the emperors allude to Maximus with expressions emphasizing his role of usurper: in CTh. 15.14.6 tyrannica audacia; in CTh. 15.14.8 tyranni usurpatione.

40 Pan. Pacatus II (XII), 31 (C.E.V. Nixon and B. Saylor Rodgers (eds.), In Praise of Later Roman Emperors. The Panegyrici Latini, with the Latin Text of R.A.B. Mynors (Berkeley 1994), 495, 664). On the panegyric of Theodosius: S. Lunn-Rockliffe, 'Commemorating the usurper Magnus Maximus. Ekphrasis, poetry, and history in Pacatus' Panegyric of Theodosius', Journal of Late Antiquity 3 (2010), 316-336. 
Despite the technical legal contents of the laws, the style of the constitutions emulates the panegyrics and their persuasive purpose; the broad circulation of the edicts allowed the emperors to build a common and loyal consent to imperial authority among the population of the empire..$^{41}$ The need for approval became more pressing when emperors had to support their legitimacy at the end of a political crisis, and the emphatic formulation of the enactments conveyed the idea of reinstating justice:

Omnia penitus amputentur, quae tyrannicum tempus poterat habere tristissima; universos ergo praecipimus esse securos. ${ }^{42}$

All the most unhappy circumstances which the time of the tyrant could afford shall be abolished entirely. Therefore We command that everyone shall be secure. ${ }^{43}$

\section{Safeguarding the Daily Life of the Empire's Inhabitants}

Erasing the usurper's actions in terms of public law, such as by abolishing constitutions or rescripts and removing officials who had collaborated with the tyrant, was bound to have severe repercussions. At the same time, however, emperors chose to confirm the validity of transactions by private citizens during the period of usurpation. During the reign of a usurper, people evidently concluded contracts, manumitted slaves, and litigated in the courts. In order to avoid the chaos resulting from cancelling all legal actions, emperors tried to mitigate the consequences of the damnatio memoriae by preserving the stability of the law.

In November 352, Constantius II issued an edict to the population of the Roman provinces and to the people of Rome, after defeating Magnentius with his troops in the Battle of Mursa Major and forcing him to retreat back to Gaul. ${ }^{44}$ Even though the usurper was still alive at this time, the emperor wanted to reassure the inhabitants of the empire:

41 A. Eich and P. Eich, 'Genese des Verlautbarungstils der spätantiken kaiserlichen Zentrale', Tyche 19 (2004), 85-87; Dillon 2012 op. cit. (n. 27), 82-89.

42 CTh. 9.38.2. The conciliatory attitude of Constantius is recognized by the emperor Julian,

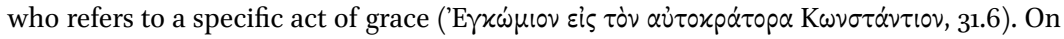
the treatment of the usurper's supporters and the emperors' amnesty: H. Leppin, 'Copying with the tyrant faction. Civil war amnesties and Christian discourses in the fourth century $\mathrm{AD}^{\prime}$ ', in Wienand 2015, op. cit. (n. 15), 198-214.

43 Pharr $195^{2}$ op. cit. (n. 26), 253.

44 On the Frankish usurper Magnentius: J.F. Drinkwater, "The revolt and ethnic origin of the 
Imp. Constantius A. et Constans C. ad universos provinciales et populum. Quae tyrannus vel eius iudices contra ius statuerunt, infirmari iubemus reddita possessione expulsis, ut qui vult ab initio agat. Emancipationes autem et manumissiones et pacta sub eo facta et transactiones valere oportet. Dat. III non. Nov. Mediolano Constantio A. v et Constante conss. ${ }^{45}$

Emperor Constantius Augustus and Constans Caesar to all the Provincials and the People. We order that all the regulations established by the tyrant and his judges contrary to law shall be invalidated. Possession shall be restored to those persons who were evicted, so that any person who wishes may litigate as from the beginning. But emancipations, manumissions, pacts, and compromises made under the tyrant, must remain valid. Given on the third day before the nones of November at Milan in the year of the fifth consulship of Constantius Augustus and the consulship of Constans-November 3, 352. ${ }^{46}$

At the opening of the constitution, the emperor ordered the invalidation of the regulations that Magnentius and his judges had established contrary to the law (contra ius). ${ }^{47}$ The emperor also decreed that possessions should be restored to the people who had been evicted. ${ }^{48}$ Next, however, he ordered that emancipations, manumissions, pacts and compromises that were made under the tyrannus were to remain valid.

Valentinian decided to preserve the effects of the same legal acts, after commanding that any declaration of law and any decisions taken by judges appointed by the usurper Magnus Maximus should be cancelled:

[Imppp. Valentinianus, Theodosius et Arcadius] aaa. Constantiano praefecto praetorio Galliarum ... Exceptis his tantum negotiis adque in sui

usurper Magnentius (350-353), and the rebellion of Vetranio (350)', Chiron 30 (2000), 131159.

45 CTh. 15.14.5.

$46 \quad$ Pharr 1952 op. cit. (n. 26), 437.

47 The expression ab initio agere possibly refers to a in integrum restitutio: the evicted regain the situation before the usurpation and can litigate as from the beginning, because the judgment is invalid. The principle of law affirmed in this constitution is in compliance with the jurists' writings. Modestinus explains that a judgment contra iuris rigorem is null and void, and a new claim can't be precluded by anything (Mod. l. s. de enucl. cas. D. 49.1.19). On D. 49.1.19: F. Pergami, Nuovi studi di diritto romano tardo antico (Turin 2014), $195^{-196 .}$

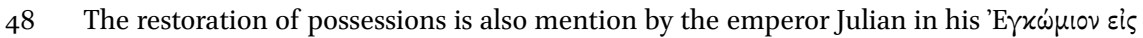

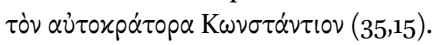


integra firmitate mansuris, quae conventionibus pactisque finita sunt, si dolo metuve caruerunt: his quoque pariter exceptis, quae donatio transtulit, emancipatio liberavit, contulit manumissio praemia meritae servitutis, quia in his omnibus voluisse sat iuris est. Dat. XviıII kal. feb. Mediolano Timasio et Promoto vv. cc. conss. ${ }^{49}$

Emperors Valentinian, Theodosius, and Arcadius Augustuses to Constantianus, Praetorian Prefect of Gaul ... Only those suits shall be excepted and remain in their complete effectiveness which were terminated by agreements and pacts, provided that fraud and fear were absent. Those legal acts are likewise excepted whereby a gift was transferred, freedom was conferred by emancipation, or the reward of manumission was bestowed upon meritorious slaves, because in all such matters the intention is a sufficient law. Given on the nineteenth day before the kalends of February at Milan in the year of the consulship of the Most Noble Timasius and Promotus.-January 14, 389. ${ }^{50}$

Pacts and agreements, such as gifts, emancipations, and manumissions, were to be excepted from the sanction of invalidation, unless all these private agreements were the consequence of fraud and fear. ${ }^{51}$ Valentinian considered that these acts were effective because they were based on the will of the person who had concluded them. Sat iuris esse means that, even in a period where there had been no law because of the illegality of the usurper's reign, the citizens of the empire had preserved the respect for the rules, which were now protected by the emperor. The emperor, in this way, recognized that the people had continued to be free in regulating on their own their economic and domestic affairs.

The opposite decision was taken when a usurper participated directly in the legal acts. Honorius, after suppressing the usurpation of Heraclianus ${ }^{52}$ and

49 CTh. 15.4.8.

$50 \quad$ Pharr 1952 op. cit. (n. 26), 438.

51 The decision of Valentinian followed the principles of the Roman legal system and seemed to have declaratory effects, not innovating. The invalidity of fraudulently induced contracts is a general remedy in the Roman law, as the actio doli in the praetorian edict shows (D. 4.3-3.1). Costantine, also, in a previous constitution, decreed that no man could invalidate what he himself willingly did and what was done according to the law during the usurpation: CTh. 15.14.2 nemo per calumniam velit quod sponte ipse fecit evertere nec quod legitime gestum est. See, Corcoran 1993 op. cit. (n. 24), 100; Dillon 2012 op. cit (n. 27), 95-96.

52 H. Menard, 'La mémoire et sa condamnation d'après les codes tardifs: l' exemple de la révolte d' Héraclien en 413 après J.C.', in S. Benoist (ed.) Mémoire et histoire. Les procédures 
commanding his damnatio memoriae, ${ }^{53}$ ordered that grants of freedom were revoked and had to be redone because the usurper had influenced directly the will of the masters:

Impp. Honorius et Theodosius aa. Hadriano praefecto praetorio ... Libertates quoque, quoniam certum est scelere eius sollemnitatem consulatus esse pollutam, in melius revocamus, sciatque dominorum voluntas iterandum esse, quod illo auctore advertit stare non posse; semel tamen mutatae condicionis beneficium implendum esse praecipimus et ita repeti manumissionum consuetudines nunc iubemus, ut nullus sub hac occasione incipiat nolle quod voluit. Dat. III non. aug. Ravennae post cons. Honorii virıI et Theodosii v. aa. ${ }^{54}$

Emperors Honorius and Theodosius Augustuses to Hadrianus, pretorian prefect, we also revoke for the better all grants of freedom, since it is certain that the legal formalities of the consulship were polluted by his criminality, and masters shall know that they must repeat their action, expressing their will, which they observe cannot be valid under his sponsorship. We direct, however, that the benefit of the changed condition of slaves must be fulfilled when the change is once made, and We now order that the customary rites of manumission shall be so repeated that no man under such pretext shall begin to unwill that which he once willed. Given on the third day before the nones of August at Ravenna in the year after the ninth consulship of Honorius Augustus and the fifth consulship of Theodosius Augustus.-August 3, 413. ${ }^{55}$

The manumissions that Heraclianus promoted personally or that were celebrated solemnly in front of him as consul were not the free and independent desire of the masters of the freed slaves, but were polluted by the criminality of the usurper. Heraclanius' presence during the ceremony undoubtedly affected

de condamnation dans l'Antiquité romaine (Metz 2007), 267-278; J.W.P. Wijnendaele, 'The manufacture of Heraclianus' usurpation (413 CE)', Phoenix 71 (2017), 138-156.

53 CTh. 15.14.13: Heracliani vocabulum nec privatim nec publice ulla memoria teneat, ideoque submovenda esse censemus, quaecumque sub eo gesta esse dicuntur (Pharr $195^{2}$ op. cit. (n. 24), 438: The name of Heraclianus shall not be preserved in private or public recollection, and We therefore decree that all the acts that are said to have been done under him shall be nullified). The decision to cancel all the acts, as affirmed in the beginning of the constitution, is very emphatic and regards the statutes of Heraclanius as well as the administrative acts of his illegitimate officials.

54 CTh. 15.14.13.

55 Pharr 1952 op. cit. (n. 26), 439. 
the masters' behaviour. The usurper might also have leveraged the masters' fear to induce them to manumit their slaves, perhaps in order to conscribe them for his own troops. ${ }^{56}$ Honorius renewed the decision of his predecessor Valentinian (CTh. 15.14.8), and accepted that the intention of releasing someone from slavery was legally sufficient if it was independent from the negative and illegal authority of a tyrannus. When, on the contrary, manumissions were affected by the pernicious influence of the usurper, he ordered that the masters had to repeat the acts.

The respect of people's liberty in performing legal acts comes to light in another constitution of Honorius, dated about eighteen years before CTh. 15.14.13 to 21 April 395: ${ }^{57}$

Impp. Arcadius et Honorius aa. Andromacho praefecto Urbi. Valeat omnis emancipatio tyrannicis facta temporibus; valeat a dominis concessa libertas; valeat celebrata et actis quibuslibet inserta donatio; valeat deficientium omne iudicium; valeat universa venditio; valeant sententiae iudicum privatorum - convelli enim iudicium non oportet—quos partium elegit adsensus et compromissi poena constituit; valeant conceptae sollemniter pactiones; valeant scripturae, quibus aut fides rerum aut ratio probatur aut debitum; valeant apud quemlibet habitae spontaneae professiones; valeat deposita super instituenda lite testatio; valeat impetratio iuris communium liberorum; valeat procuratio scaevis mandata temporibus; datus tutor vel curator optineat firmitatem; valeat in sponsam perfecta largitio; doli ac vis et metus inchoata actio in tempus legitimum perseveret; bonorum admissa possessio et adfectus adeundae hereditatis obtineat et interdicti beneficium non amittat; valeat in integrum restitutionis petitum auxilium; valeat vindicatio .... identidem desiderata tribuatur; locatio et conductio inviolabilem obtineant firmitatem; interdicti beneficia tempora infausta non mutilent; postulata inofficiosi actio et inmodicarum donationum rescissio petita servetur; beneficia transacta non titubent; sacramento terminata permaneant; pignoris adque fiduciae obligatio perseveret. Stent denique omnia, quae in placitum sunt deducta privatum, nisi aut circumscriptio subveniet aut vis aut terror ostenditur. Funestorum tantum consulum nomina iubemus aboleri, ita ut his reverentia in lectione recitantium tribuatur, qui tunc in Oriente annuos mag-

$5^{6}$ J.M. Kondek, 'Abrogation of legal effects of usurpations in the Late Roman Empire', Miscellanea Historico-Iuridica 11 (2012), 53.

57 On this constitution: Lovato 2014 op. cit. (n. 22), 349-351; Lovato 2009, op. cit. (n. 22), 405406; Aubert 2016 op. cit. (n. 22), 588-591. 
istratus victuris perpetuo sunt fascibus auspicati; tempus vero ipsum, ac si non fuerit, aestimetur, si quidem tunc temporis omissa aliqua praescriptio taciturnitatis etiam de illis, quae confirmavimus, non possit obponi. Dat. XI kal. mai. Mediolano Olybrio et Probino conss. ${ }^{58}$

Emperors Arcadius and Honorius Augustuses to Andromachus, Prefect of the City. Every emancipation made in the times of the tyrant shall remain valid; all grants of freedom by masters shall remain valid; all gifts made and registered in any records shall remain valid; every will of deceased persons shall remain valid; every sale shall remain valid; the decisions of private judges, chosen by the assent of the parties and appointed under penalty of a mutual promise to abide by the award, shall remain valid, since judgments once rendered must not be disturbed; pacts that were formally made shall remain valid; written documents by which the trustworthiness of transactions or the reason there for or debts are proved shall remain valid; declarations voluntarily made before any person shall remain valid; attestations filed for the institution of suits shall remain valid; impetrations of special privileges that accrue to parents on account of their common children shall remain valid; procurator ships entrusted during the untoward times shall remain valid; the appointments of tutors and curators shall retain their validity; a completed gift to a betrothed woman shall remain valid; an action for fraud or one on account of violence and intimidation, when once instituted, shall remain effective during the statutory time limits; a grant of the possession of the goods of an inheritance and the expressed will to enter on an inheritance shall prevail, and shall not lose the benefit of the interdict; the aid sought for restoration to the original condition shall remain valid; vindications shall remain valid, and any such action often requested shall be granted; letting and hiring shall retain inviolable effectiveness; the inauspicious times shall not mutilate the benefits of an interdict; requested actions against inofficiosity and the petitioned rescission of immoderate gifts shall be preserved; completed benefits shall not waver; transactions terminated by an oath shall remain valid; the obligation of a pledge or a trust shall persist. Finally, every transaction shall stand firm which was embodied in a private pact, unless either circumvention entered therein or duress or intimidation is shown. We order that the names of the calamitous consuls only shall be abolished, but reverence shall be paid in the public recital 
of readers to those persons who at that time in the Orient administered the annual magistracies under Our ever victorious fasces. The very time of the tyranny shall be considered as though it had not been, since any prescription of silence omitted at that time cannot be brought, even in regard to those matters which We have confirmed. Given on the eleventh day before the kalends of May at Milan in the year of the consulship of Olybrius and Probinus.—April 21, $395^{59}$

Addressed to Andromachus, praefectus urbis, this imperial enactment concerns the usurper Eugenius. ${ }^{60}$ Honorius preserved the effects of the legal acts performed by citizens during the usurpation. The emperor tried to cover all private law, and the constitution implied a very good knowledge of the praetorian edict, as the references of many of its institutions show. For contracts, both formal and informal, he listed e.g. sale, hire, agency, pledge and fiducia; for the law of succession, he cited the acquisitions of inheritance, the bonorum possessio, as well as the remedies of the heir; for the law of procedure, he remembered the litis contestatio and the in integrum restitutio; he did not forget the law of family, quoting emancipation, guardianship and gifts for marriage. The long list of legal acts ends with a general provision. The emperor recognized the validity of all acts that had not been indicated in the list and that were embodied in a private agreement (omnia, quae in placitum sunt deducta privatum), provided that they had not been concluded dolo or $v i$.

The constitution then resolved the problem of the formality of the acts that was the result of deleting in the documents ${ }^{61}$ the names of the consuls $^{62}$ appointed by the tyrannus. The nomen consulis was a necessary requirement for an act to be legally valid, and its importance is clearly evoked by John Chrysostom. ${ }^{63}$ Yet, in the present case, the emperor decreed that the

$59 \quad$ Pharr 1952 op. cit. (n. 26), 438.

6o J. Szidat, 'Die Usurpation des Eugenius', Historia 28 (1979), 487-508; Leppin 2003 op. cit. (n. 18), 247-255.

61 On the cancellation in official documents: H.I. Flower, 'Memory sanctions and the disgrace of emperors in official documents and laws', R. Haensch (ed.), Selbstdarstellung und Kommunikation. Die Veröffentlichung staatlicher Urkunden auf Stein und Bronze in der Römischen welt, (Munich 2009), 409-421.

62 For Hendrick (History and Silence. Purge and Rehabilitation of Memory in Late Antiquity (Austin 200o), 95) those who served as consuls under Eugenius have their names struck from the record. Contrary, Honoré 1998 op. cit. (n. 36) 65 suggests that the constitution concerns the annulment of the consular appointment; the same idea is accepted by: Kondek 2012 op. cit. (n. 5o), 49.

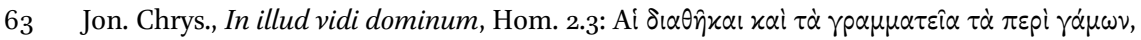

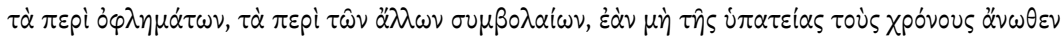


omission of the consuls' names did not invalidate the contracts and all the other private regulations. Using a fictio, he denied that the praescriptio was able to invalidate these agreements, which the authority of the legislator confirmed.

From a political and ideological point of view, the constitution clearly states that there was a time of the usurper (tyrannicis temporibus / scaevis temporibus I tempora infausta), but that now the time of justice is back. Honorius wanted to erase the time of usurpation, tempus vero ipsum, ac si non fuerit, aestimetur: the time of usurpation must be considered as having never existed, as if no usurpation had ever occurred. However, asserting that the time of the usurpation had never existed threatened the certainty and the stability of relations between the individuals. For this, the emperor gave effect to all private acts, and he based this solution on his power, which was legitimately exercised. The emperor presents himself as the only one able to guarantee the existence and effectiveness of all the actions taken by the citizens during the time of usurpation. The repetition of the verb valeat stresses that the emperor assures the serenity and the prosperity of the empire and safeguards peace among the citizens.

The idea that power is now legitimately exercised after the usurper's fall also emerges in the decision to ensure reverentiam in lectione recitantium only for legitimate consuls. In the courts of the empire, only the emperor's time would resound, while oblivion fell on the usurper's period. The same emperor emphasized this thought in CTh. 9.38.12, in which he released an act of grace for those awaiting trial and for the convicted. By celebrating the defeat of the usurper Priscus Attalus in 410, he affirmed that the state had been freed from tyrannidis iniuria, i.e. a period of no law (in-ius). ${ }^{64}$

Honorius' validation of private acts answers to the need to secure the trust of his subjects in imperial power and to strengthen the period of peace after the conflict with the usurper. By doing this, he protects the principle of legal certainty, because the law is certain when the subjects can predict the consequences of their conduct and see the effects of their legal action maintained over time. This principle of law, adopted in the Roman legal system, is a con-

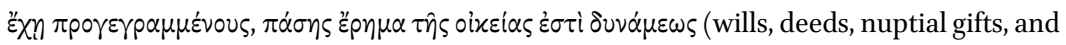
all other contracts are not valid and are void of any effectiveness, if the indication of the consulship is missing at the beginning of the document).

64 CTh. 9.38.12 Liberata re publica tyrannidis iniuria omnium criminum reos relaxari praecipimus. On this constitution, O.F. Robinson, 'Unpardonable crimes. Fourth century attitudes', in J. Cairns and O. Robinson (eds.), Critical Studies in Ancient Law, Comparative Law and Legal History (Oxford 2001), 121. 
stant in the political programme of all the emperors. For example, Marcianus, in a lex of 4 April 454, stated that he wanted to remove obscuritas and bring certainty to the laws:

Si quid vero in iisdem legibus latum fortassis obscurius fuerit, oportet id imperatoria interpretatione patefieri, ut omnis sanctionis removeatur ambiguum et in suam partem iuris dubia derivare litigatorum contentio alterna non possit. ${ }^{65}$

If any regulation issued in the aforesaid laws should perhaps be rather obscure, it must be clarified by the interpretation of the Emperor. Thus the ambiguity of every sanction shall be removed, and the alternate contention of litigants cannot divert doubtful points of law to their own advantage. ${ }^{66}$

\section{The Emperor is also vó $\mu \circ \varsigma$ है $\mu \psi \cup \chi \circ \varsigma$ during Political Crises}

This brief survey of texts has demonstrated how constitutions function as vehicles for the public advertisement of emperors' legitimacy after political crises caused by usurpation. Constantine and Theodosius emphasized that they restored the law, while the usurper was turned into the personification of the absence of any kind of order and justice. In addition, Valentinian and Honorius claimed that they were guardians of the stability of the rules by recognizing the validity of the legal acts of private citizens while they were subject to the power of the tyrannus.

This account traced the connection between emperors and law, which characterized all legal experience in Late Antiquity. The power of issuing enactments was not simply a prerogative of the emperor, but became one of the essential features of his persona. In Late Antique imperial ideology the emperor was not only the source of the law but the law itself. ${ }^{67}$ Libanius defines the emperor as master of the law, ${ }^{68}$ an expression which evokes the phrase $\tau 0 \hat{v}$

65 Nov. Marc. 4. See, D. Mantovani, 'Per una mappa concettuale della certezza del diritto: idee romane e contemporanee' (forthcoming).

66 Pharr 1952 op. cit. (n. 26), 565.

67 G. Bassanelli Sommariva, L'imperatore unico creatore ed interprete delle leggi e l'autonomia del giudice nel diritto giustinianeo, Milano 1983, 5-33; S. Puliatti, Il diritto prima e dopo Costantino, in Costantino I (Rome 2013), 599-613.

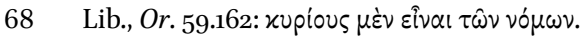




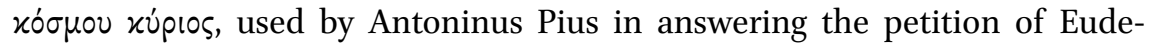
mone. ${ }^{69}$ Themistius, in his encomium, displays Theodosius as living law and superior to all the written rules. ${ }^{70}$

The ideological system that the emperors manipulated to obtain the subjects' consensus survived also during usurpations, a period where rival claims of succession in the imperial power shook the routine of the empire's life. After the removal of the defeated enemy, the language of power, through imperial constitutions, aimed to convince all inhabitants of the empire that the triumph of the emperor restored the rule of law, which had been lost under the "tyranny" of the opponent. Legislation, connected to the communicative framework of the imperial regime, promoted in a very effective way the image of an emperor as legum dominus Romanorum, iustitiae aequitatis rector. ${ }^{71}$

69 Vol. Maec. ex lege Rhodia D. 14.2.9. On this text: V. Marotta, Onnipresenza dell'imperatore e ubiquità dell'urbs. Esercizio e trasmissione del potere imperiale (secoli I-IV d.C.) (Turin 2016), 99-103.

70 Them., Or. 16.213a. On Themistius and the emperor Theodosius:J. Vanderspoel, Themistius and the Imperial Court. Oratory, Civic Duty, and Paideia from Constantius to Theodosius (Ann Arbor 1995), 187-216; P. Heather, 'Themistius: a political philosopher', in M. Whitby (ed.), The Propaganda of Power. The Role of Panegyric in Late Antiquity (Leiden 1998), 12515o; P. Heather, 'Liar in winter. Themistius and Theodosius', in S. McGill, C. Sogno and E. Watts (eds.), From the Tetrarchs to the Theodosians. Later Roman History and Culture, 284-450 CE (Cambridge 2010), 185-214.

71 ILS 765; L. De Giovanni, 'L'esperienza giuridica nella Tarda antichità', in S. Puliatti (ed.), L'ordine costituzionale come problema storico (Turin 2017), 4. 